\title{
Synthesis of chloro and methyl imido cyclopentadienyl molybdenum and tungsten complexes. X-ray molecular structures of $\left[\mathrm{WCp}^{*} \mathrm{Cl}_{3}\left(\mathrm{NBu}^{\mathrm{t}} \mathrm{Bu}\right.\right.$, $\left[\mathrm{MoCp}^{*} \mathrm{ClMe}_{2}\left(\mathrm{~N}^{t} \mathrm{Bu}\right)\right]$ and $\left[\mathrm{WCp}^{*} \mathrm{ClMe}_{2}\left(\mathrm{~N}^{t} \mathrm{Bu}\right)\right]^{1}$
}

\author{
P. Gómez Sal ${ }^{2}$, Ignacio Jiménez, Avelino Martín ${ }^{3}$, Teresa Pedraz, Pascual Royo *, \\ Alberto Sellés, Amelio Vázquez de Miguel \\ Departamento de Quimica Inorgánica, Universidad de Alcalá de Henares, Campus Universitario, E-2887I Alcalá de Henares, Spain
}

Received 6 May 1997; revised 16 June 1997; accepted 18 July 1997

\begin{abstract}
Alternative methods to prepare $\left[\mathrm{MCp}^{\prime} \mathrm{Cl}_{4}\right],\left[\mathrm{MCp}^{\prime} \mathrm{Cl}_{2}\left(\mathrm{~N}^{\prime} \mathrm{Bu}\right)\right]$ and $\left[\mathrm{MCp}^{\prime} \mathrm{Cl}_{3}\left(\mathrm{~N}^{\prime} \mathrm{Bu}\right)\right]\left[\mathrm{M}=\mathrm{Mo}, \mathrm{Cp}^{\prime}=\eta^{5}-\mathrm{C}_{5} \mathrm{Me}_{5}\left(\mathrm{Cp}^{*}\right) ; \mathrm{M}^{2}=\mathrm{W}\right.$, $\left.\mathrm{Cp}^{\prime}=\eta^{5}-\mathrm{C}_{5} \mathrm{H}_{5}(\mathrm{Cp}), \eta^{5}-\mathrm{C}_{5} \mathrm{Me}_{5}\left(\mathrm{Cp}^{*}\right)\right]$ in high yields are reported. Alkylation of $\left[\mathrm{MCp}^{\prime} \mathrm{Cl}_{3}\left(\mathrm{~N}^{\prime} \mathrm{Bu}\right)\right]$ with stoichiometric amounts of LiMe or $\mathrm{MeMgCl}$ under appropriate conditions leads to the dimethyl $\left[\mathrm{MCp}^{\prime} \mathrm{ClMe}_{2}\left(\mathrm{~N}^{\prime} \mathrm{Bu}\right)\right]$ and trimethyl $\left[\mathrm{MCp}^{\prime} \mathrm{Me} \mathrm{N}_{3}\left(\mathrm{~N}^{\prime} \mathrm{Bu}\right)\right],(\mathrm{M}=\mathrm{Mo}$, $\mathrm{Cp}^{\prime}=\mathrm{C} \mathrm{p}^{*} ; \mathrm{M}=\mathrm{W}, \mathrm{Cp}^{\prime}=\mathrm{Cp}, \mathrm{Cp}^{*}$ ) complexes. The 18-electron trimethyltungsten complex $\left[\mathrm{WCp}^{*} \mathrm{Me}_{3}\left(\mathrm{~N}^{\prime} \mathrm{Bu}\right)\right]$ reacts very slowly with $\mathrm{CN}\left(2,6-\mathrm{Me}_{2} \mathrm{C}_{6} \mathrm{H}_{3}\right)$ to give the insertion product [WCp* $\left.\left[\mathrm{C}(\mathrm{Me})=\mathrm{N}\left(2,6-\mathrm{Me}_{2} \mathrm{C}_{6} \mathrm{H}_{3}\right)\right\} \mathrm{Me}_{2}\left(\mathrm{~N}^{\prime} \mathrm{Bu}\right)\right]$. All of the new compounds reported were characterized by elemental analyses, IR and $\mathrm{NMR}$ spectroscopy and the X-ray molecular structures of $\left[\mathrm{WCp}^{*} \mathrm{Cl}{ }_{3}\left(\mathrm{~N}^{\prime} \mathrm{Bu}\right)\right]$, $\left[\mathrm{MoCp}^{*} \mathrm{ClMe}_{2}\left(\mathrm{~N}^{\prime} \mathrm{Bu}\right)\right]$ and [ $\left.\mathrm{WCp}{ }^{*} \mathrm{ClMe}_{2}\left(\mathrm{~N}^{\prime} \mathrm{Bu}\right)\right]$ have been determined by diffraction methods. $\mathrm{O}$ 1998 Elsevier Science S.A. All rights reserved.
\end{abstract}

Kerwords: Molybdenum complexes; Tungsten complexes; Imido complexes; Alkyl complexes; Cyclopentadienyl complexes; Crystal structures

\section{Introduction}

The chemistry of organoimido molybdenum and tungsten complexes has received much attention in the last few years because the imido ligand provides the desired electronic and steric control for molybdenum complexes to act as catalysts for ring-opening metathesis polymerization (ROMP) of cyclic olefins [ 1] and cyclopolymerization of acelylenes [2]. Formation of imido species has also been proposed as an intermediate step in the ammonoxidation of olefins [3]. Numerous terminal and bridging imido complexes of molybdenum [4] and tungsten $|5|$ have been reported and the synthesis, structural characterization and reactivity of these types of compounds have been reviewed [6|. Related imido cyclopentadienyl complexes have also been studied, and a number of molybdenum and tungsten compounds have been reported [7]. We have previously reported the synthesis and reactivity of new tantalum [8], molybdenum and tungsten

\footnotetext{
* Corresponding author. Tel.: + 3418854765 ; fax: + 3418854683 .

' Dedicated to a good scientist and good friend, Ivano Bertini.

$\mathrm{X}$-ray diffraction studies.

${ }^{2} \mathrm{X}$-ray diffraction studies.
}

[9] derivatives. In this work we present the results of our studies on the synthesis of chloro imido cyclopentadienyl molybdenum and tungsten( $\mathrm{V}$ ) and (VI) compounds, their alkylation with Grignard and lithium reagents and the $X$-ray crystal structures of three of the new complexes.

\section{Results and discussion}

\subsection{Synthesis of $\left[M \mathrm{Mp}^{\prime} \mathrm{Cl}_{2}\left(\mathrm{~N}^{\prime} \mathrm{Bu}\right)\right]$}

The best method to prepare cyclopentadienyltungsten ( $V$ ) chlorides is the oxidation of low valent tungsten carbonyls based on the method first reported by Schrock and co-workers [10] to obtain [ $\left.\mathrm{WCpCl}_{4}\right]$ by chlorination of $\left[\mathrm{WCp}(\mathrm{CO})_{3-}\right.$ $\mathrm{Me}$ ] with $\mathrm{PCl}_{5}$. However, the tedious isolation of the methyl carbonyl complex can be avoided, and the same method has subsequently been extended [11] to many other carbonyl derivatives which can be easily oxidized in a similar reaction. Using a modification of the method previously reported [12] we isolated the complex $\left[\mathrm{W}(\mathrm{CO})_{3}(\mathrm{NCMe})_{3}\right]$ and used this compound instead of $\mathrm{W}(\mathrm{CO})_{6}[13]$ to prepare [ $\left.\mathrm{WCp}(\mathrm{CO}){ }_{3} \mathrm{H}\right]$ in yields higher than $95 \%$ by reaction with 


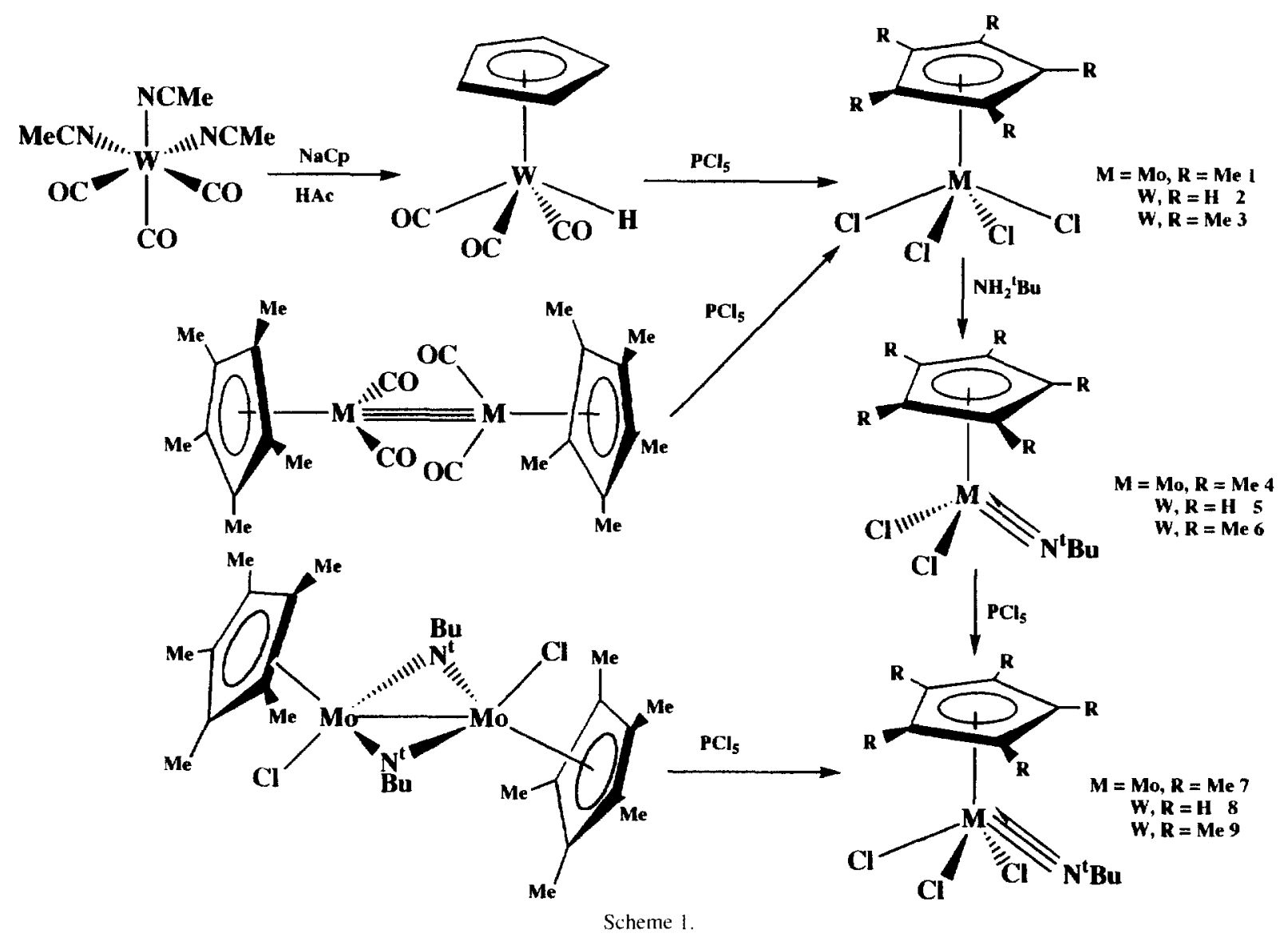

$\mathrm{NaCp}$ and subsequent addition of acetic acid in THF without isolation (Scheme 1). The compounds $\left[\mathrm{MCp}^{*}(\mathrm{CO})_{2} \mathrm{I}_{2}\right.$ ( $\mathrm{M}=\mathrm{Mo}, \mathrm{W}$ ) were prepared as previously described [14].

Treatment of $\left[\mathrm{WCp}(\mathrm{CO})_{3} \mathrm{H}\right]$ and $\left[\mathrm{MCp} *(\mathrm{CO})_{2}\right]_{2}$ $\left(\mathrm{M}=\mathrm{Mo}, \mathrm{W}\right.$ ) with an excess of $\mathrm{PCl}_{5}$ in dichloromethane and toluene respectively followed by filtration afforded the almost insoluble complexes $\left[\mathrm{MCp}^{\prime} \mathrm{Cl}_{4}\right],\left(\mathrm{M}=\mathrm{Mo}, \mathrm{Cp}^{\prime}=\eta^{5}-\mathrm{C}_{5} \mathrm{Me}_{5}\right.$ (1) $[10 \mathrm{a}] ; \mathrm{M}=\mathrm{W}, \mathrm{Cp}^{\prime}=\eta^{5}-\mathrm{C}_{5} \mathrm{H}_{5}$ (2) [11], $\eta^{5}-\mathrm{C}_{5} \mathrm{Me}_{5}$ (3) [10b]) in yields higher than $90 \%$.

Reaction of complexes 1-3 with tert-butylamine led to the reported complexes $\left[\mathrm{MCp}^{\prime} \mathrm{Cl}_{2}\left(\mathrm{~N}^{\prime} \mathrm{Bu}\right)\right] \quad\left(\mathrm{M}=\mathrm{Mo}, \mathrm{Cp}^{\prime}=\right.$ $\eta^{5}-\mathrm{C}_{5} \mathrm{Me}_{5}$ (4) $[7 \mathrm{e}, 15] ; \mathrm{M}=\mathrm{W}, \mathrm{Cp}^{\prime}=\eta^{5}-\mathrm{C}_{5} \mathrm{H}_{5}$ (5) $\left.\mid 7 \mathrm{a}, 16\right]$, $\left.\eta^{5}-\mathrm{C}_{s} \mathrm{Me}_{5}(6)[7 \mathrm{e}]\right)$.

\subsection{Oxidation of $\left[\mathrm{MCp}^{\prime} \mathrm{Cl}_{2}\left(\mathrm{~N}^{\prime} \mathrm{Bu}\right)\right]$}

Addition of $0.5 \mathrm{~mol}$ of $\mathrm{PCl}_{5}$ to a dichloromethane solution of complex [ $\left.\mathrm{MoCp}^{*} \mathrm{Cl}_{2}\left(\mathrm{~N}^{t} \mathrm{Bu}\right)\right]$ (4) led to the formation of the trichloro imido molybdenum(VI) complex [MoCp*$\left.\mathrm{Cl}_{3}\left(\mathrm{~N}^{\mathrm{t}} \mathrm{Bu}\right)\right]$ (7) [7a], which could also be obtained by reaction of the imido molybdenum(IV) derivatives cis-trans$\left[\mathrm{MoCp} * \mathrm{Cl}\left(\mathrm{N}^{t} \mathrm{Bu}\right)\right]_{2}[15]$ with $1 \mathrm{~mol}$ of $\mathrm{PCl}_{5}$. Oxidation of complexes $5-6$ with 1 equiv. of $\mathrm{PCl}_{5}$ led to the formation of the reported [7a] [ $\left.\mathrm{WCp}^{\prime} \mathrm{Cl}_{3}\left(\mathrm{~N}^{\prime} \mathrm{Bu}\right)\right]\left(\mathrm{Cp}^{\prime}=\eta^{5}-\mathrm{C}_{5} \mathrm{H}_{5}\right.$ (8), $\mathrm{Cp}^{\prime}=\eta^{5}-\mathrm{C}_{5} \mathrm{Me}_{5}(9)$ (Scheme 1). Related molybdenum and tungsten complexes containing different cyclopentadienyl rings were also isolated using chlorine gas as the oxi- dizing agent [16] and by selective reaction of the diimidometal(VI) derivatives $\left[\mathrm{MCp}{ }^{*} \mathrm{Cl}\left(\mathrm{N}^{\mathrm{t}} \mathrm{Bu}\right)_{2}\right]$ with $\mathrm{HCl}$ [7a]. However, the oxidation of the imidomolybdenum( $\mathrm{V}$ ) complexes described here is the most direct and easiest method to prepare the corresponding molybdenum(VI) compounds in high yield.

Complexes 7-9 were isolated as crystalline solids which were characterized by elemental analysis and IR and NMR spectroscopy ( see Section 3 ) and the molecular structure of complex 9 was studied by X-ray diffraction methods.

The molecular structure of complex 9 is shown in Fig. 1 along with the labelling scheme. Selected bond distances and angles are presented in Table 1. The molecule shows a pseudo-square pyramidal coordination where the four square planar positions are occupied by the three chlorine atoms and the nitrogen atom of the imido $\mathrm{N}^{\prime} \mathrm{Bu}$ group.

The $C p$ (centroid) $-W$ distance is a normal $2.121 \AA$, but the $W-C(C p)$ distances range from 2.297(6) to 2.595(6), showing an important trans influence of the $N^{\prime} B u$ substituent which is responsible for the longest $\mathrm{C} 3-\mathrm{W} 1$ distance. All the $\mathrm{W}-\mathrm{Cl}$ distances are similar. The $\mathrm{W} 1-\mathrm{N} 1$ distance of $1.736(4) \AA$ and the WI-N $1-\mathrm{C} 21$ angle $174.8(4)^{\circ}$ confirm the linear coordination of the formally triple bonded imido group. This structure is similar to that found for $\mathrm{MoCp}^{*} \mathrm{Cl}_{3}\left(\mathrm{~N}^{\prime} \mathrm{Bu}\right)$. The $\mathrm{Wl}-\mathrm{N} 1$ distance is even shorter than that found [17] for $\mathrm{W}\left(\eta^{5}-\mathrm{C}_{5} \mathrm{Me}_{5}\right)(=\mathrm{NAr})_{2} \mathrm{Cl}$ where the 


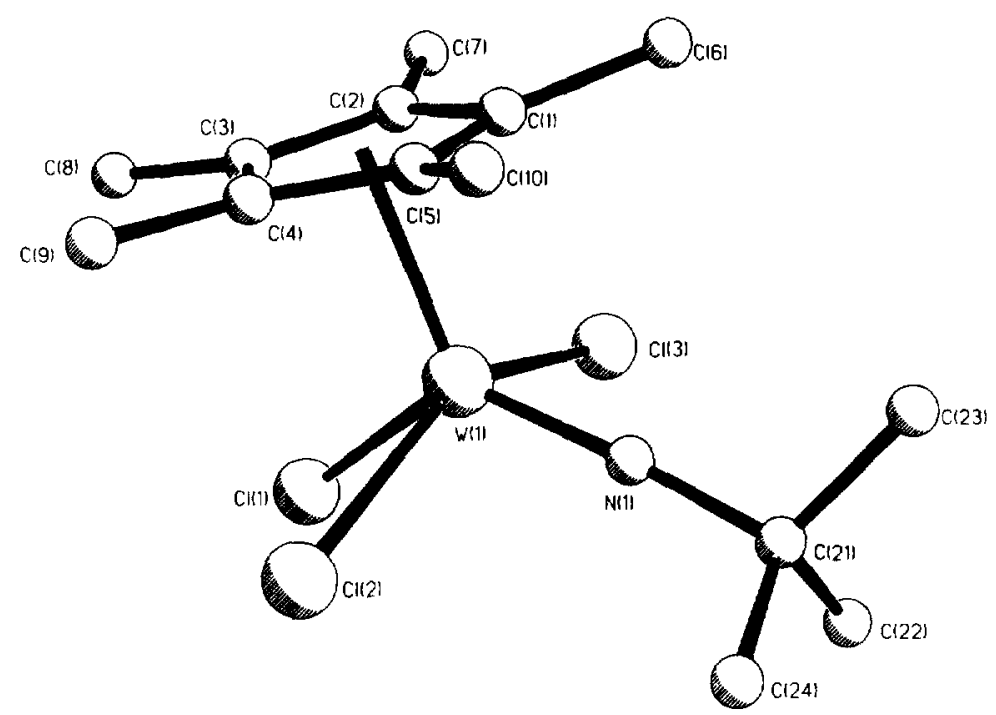

Fig. 1. Perspective view of the molecular structure of $\left|\mathrm{WCp}^{*} \mathrm{Cl}_{3}\left(\mathrm{~N}^{\prime} \mathrm{Bu}\right)\right|(9)$ with the atom-numbering scheme. Hydrogen atoms are omitled for clarity

Table 1

Solected bond lengths $(A)$ and angles $(")$ for 9

\begin{tabular}{|c|c|c|c|}
\hline$W(1)-N(1)$ & $1.7 .36(4)$ & $\mathrm{W}(\mathrm{I})-\mathrm{Cl}(\mathrm{l})$ & $2.410(2)$ \\
\hline$W(1)-(1,2)$ & $2.402(2)$ & $W(1)-C l(3)$ & $2.402(2)$ \\
\hline$W(1)-(1)$ & $2.302(5)$ & $W(1)-C(2)$ & $2.496(5)$ \\
\hline$W(1)-(1,3)$ & $2.595(5)$ & $W(1)-C(4)$ & $2.488(5)$ \\
\hline$W(1)-(15)$ & $2.297(5)$ & $N(1)-C(21)$ & $1.444(7)$ \\
\hline$(1)-(15)$ & $1.416(8)$ & $C(1)-C(2)$ & $1.425(8)$ \\
\hline$(12)-C(3)$ & $1 .+16(8)$ & $\mathrm{C}(3)-\mathrm{C}(4)$ & $1.407(8)$ \\
\hline$C(+)-C(5)$ & $1.425(8)$ & $C(21)-C(22)$ & $1.529(11)$ \\
\hline$(121)-C(23)$ & $1.5090(12)$ & $C(21)-C(24)$ & $1.473(12)$ \\
\hline$w(1)-(p(1)$ & 2.121 & & \\
\hline $\mathrm{N}(1)-\mathrm{Wi} 1)-\mathrm{Cl}(2)$ & $86.4(2)$ & $\mathrm{N}(1)-\mathrm{W}(1)-\mathrm{Cl}(3)$ & $87.1(2)$ \\
\hline$(112)-W(1)-C l(3)$ & $145.77(7)$ & $\mathrm{N}(1)-\mathrm{W}(1)-\mathrm{Cl}(1)$ & $128.8(2)$ \\
\hline$(112)-W(1)-C l(1)$ & $79.03(7)$ & $\mathrm{Cl}(3)-\mathrm{W}(1)-\mathrm{Cl}(1)$ & $79.11(8)$ \\
\hline$(121)-N(1)-W(1)$ & $174.8(4)$ & & \\
\hline
\end{tabular}

(pi) in the centroid of the (1) to C(5) ring.

W-N distance is $1.785(4) \AA$ and the proposed bond order is greater than two.

\subsection{Alkvation of $\left|M C p^{\prime} C l,\left(N^{\prime} B u\right)\right|$}

Alkylation of complex 7 with 2 equiv. of LiMe in diethylether gave the dimethyl complex [ $\left.\mathrm{MoCp}^{*} \mathrm{ClMe}_{2}\left(\mathrm{~N}^{\prime} \mathrm{Bu}\right)\right]$ (10), which was isolated as a crystalline yellow solid after cooling the solution to $-78^{\circ} \mathrm{C}$ (Scheme 2 ). The analogous reaction using 3 equiv. of the same alkylating agent led to the trimethyl complex [ $\left.\mathrm{MoCp}^{*} \mathrm{Me}_{3}\left(\mathrm{~N}^{\prime} \mathrm{Bu}\right)\right]$ ( 13 ) als a microcrystalline orange solid. Both alkyl compounds $\mathbf{1 0}$ and $\mathbf{1 3}$ were moderately air-stable in the solid and very soluble in all organic solvents although they decomposed on heating their solutions above $70^{\circ} \mathrm{C}$ to give unidentified brown paramagnetic products. They were characterized by elemental analyses. IR and NMR spectroscopy and the molecular structure of complex 10 was determined by $\mathrm{X}$-ray diffraction.

The molecular structure of $\mathbf{1 0}$ is shown in Fig. 2, along with the labelling scheme. Only one of the enantiomers was observed. Selected bond distances and angles are presented in Table 2.

The coordination of the Mo atoms is similar to that described for complex 9 . In this case the unique chlorine atom is located trans to the $\mathrm{N}^{\prime} \mathrm{Bu}$ group and together with the other two trans methyl groups complete the square base of the pseudo-square pyramid whose apex is occupied by the $\eta^{5}$ pentamethylcyclopentadienyl ligand. The $\mathrm{Cp}$ (centroid)Mo-Cll and $\mathrm{Cp}$ (centroid)-Mo-N angles are 110.3 and $126.3^{\circ}$, respectively. They are larger than the other two ( mean $108.0^{\circ}$ ) and the $\mathrm{N}$ atom is slightly out-of-the plane of the base of the pyramid, probably due to the steric requirement of the bulky N'Bu group. The trans influence due to the imido $\mathrm{N}^{\prime} \mathrm{Bu}$ is also remarkable, giving rise to the largest $\mathrm{Mo}-$ $\mathrm{C} 12(\mathrm{Cp})$ distance of $2.53(1) \AA$. The $\mathrm{Mo}(1)-\mathrm{C}$ (methyl) distances of $2.25(1) \AA$, correspond to normal single bonds and the $\mathrm{Mo}(1)-\mathrm{N}(1)$ distance of $1.706(8) \AA$ and the Mo$\mathrm{N}(1)-\mathrm{C}(3)$ angle of $175.1(9)^{\circ}$ are consistent with the triple bond character of the $\mathrm{Mo}-\mathrm{N}$ bond.

The methylation of complexes $\mathbf{8}$ and $\mathbf{9}$ was studied using different molar ratios of LiMe and MgClMe as alkylating agents. Addition of 1 equiv. of the alkylating agent to suspensions of complexes 8 and 9 in THF or toluene always led to unresolvable mixtures containing the unreacted starting complex and variable amounts of the dialkyl and trialkyl derivatives together with traces of a paramagnetic component, which is probably the reduced tungsten $(V)$ complex when LiMe was used. The addition of 2 equiv. of $\mathrm{MgClMe}$ to a toluene suspension of $\left[\mathrm{WCpCl}_{3}\left(\mathrm{~N}^{\prime} \mathrm{Bu}\right)\right](\mathbf{8})$ led after stirring for $16 \mathrm{~h}$ at room temperature to a green solution, which after purification by chromatography aftorded the dimethyl complex [ $\left.\mathrm{WCpClMe}_{2}\left(\mathrm{~N}^{\prime} \mathrm{Bu}\right)\right]$ (11) as a green crystalline solid in $40 \%$ yield. The same reaction carried out with $\left[\mathrm{WCp}^{*} \mathrm{Cl}_{3}\left(\mathrm{~N}^{\prime} \mathrm{Bu}\right)\right](9)$ in THF allowed us to isolate the related complex $\left[\mathrm{WCP}^{*} \mathrm{ClMe}_{2}\left(\mathrm{~N}^{\prime} \mathrm{Bu}\right) \mid(\mathbf{1 2})\right.$ as yellow crystals in $45 \%$ yield. LiMe can be alternatively used to prepare complex 12 under the same conditions, whereas a 

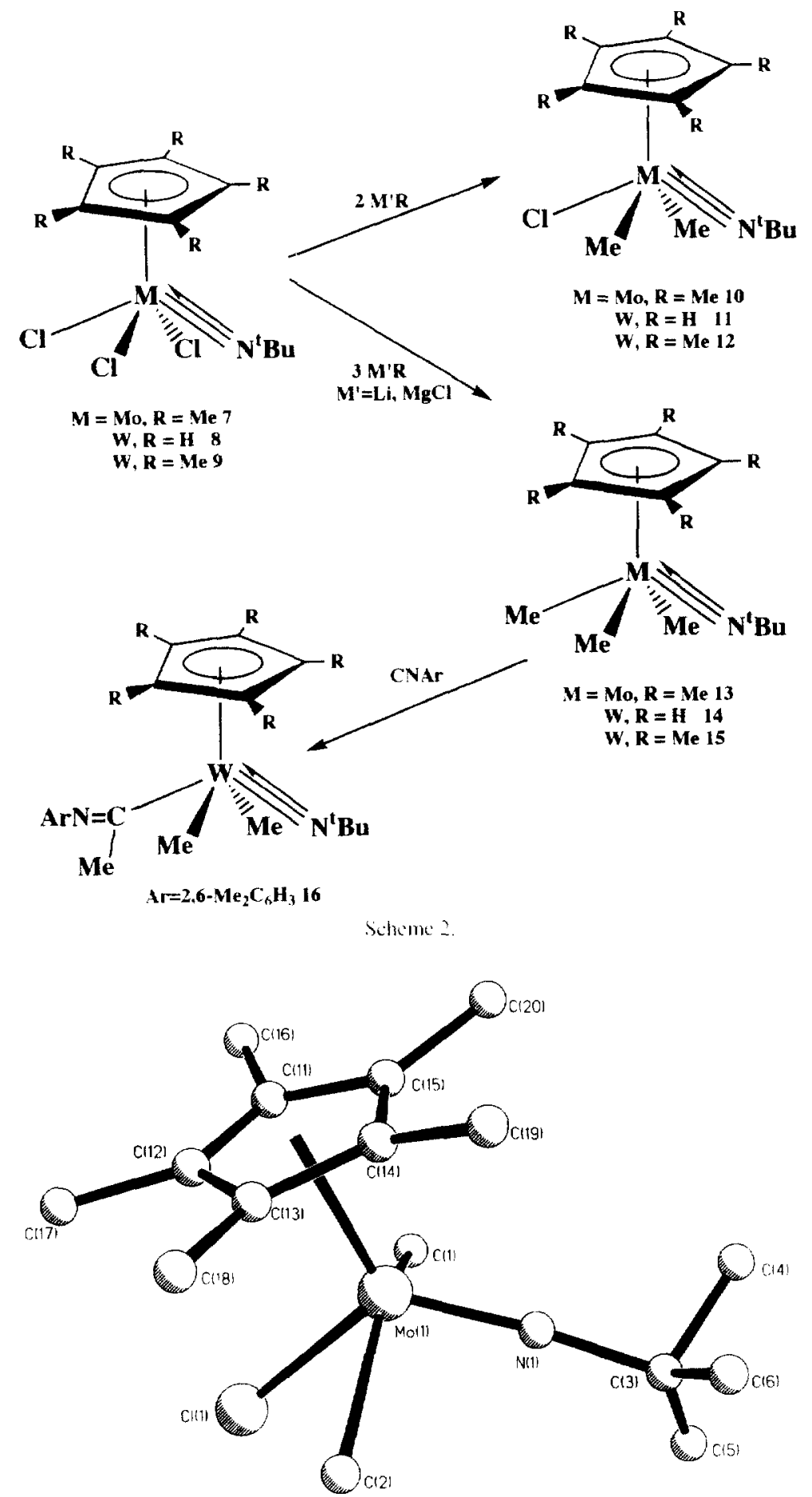

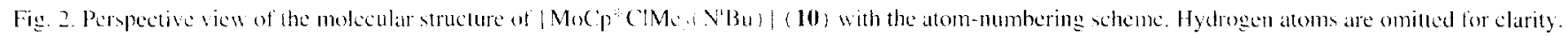

lower yield due to the formation of other unidentitied products was obtained when this alkylating agent was used 10 prepare complex 11. Addition of 3 equiv. of $\mathrm{MgClMe}$ to a THF suspension of $\left|\mathrm{WCpCI}_{(}\left(\mathrm{N}^{\prime} \mathrm{Bu}\right)\right|$ ( 8 ) led to an unre. solvable mixture of alkylated products, but the related trimethyl derivative / WCpMe, $\left(N^{\prime} B u\right) \mid(14)$ could be easily prepared in $50 \%$ yield as a yellow brown solid by reating the previously isolated dimethyl complex 11 with 1 equiv. of MgClMe in toluene. The same methylation of /WCp:-
$\mathrm{Cl}_{3}\left(\mathrm{~N}^{\prime} \mathrm{Bu}\right) \mid(9)$ with 3 equiv. of MgClMe or LiMe produced an initially green solution, which after warming and stirring at $0^{\circ} \mathrm{C}$ changed to give a brown solution which after purification by chromatography provided yellow crystals of the trimethyl complex $\left[\mathrm{WCp} \mathrm{Me}_{4}\left(\mathrm{~N}^{\prime} \mathrm{Bu}\right)\right] 15|18|$ in $35 \%$ yield. Complex 15 is a rather stable 18-electron compound. which reacts very slowly with an excess of $\mathrm{CN}(2.6-$ $\mathrm{Me}_{2} \mathrm{C}_{6} \mathrm{H}_{3}$, when heated in a sealed ampoule to $65^{\circ} \mathrm{C}$ for more than 10 days, affording the froms-dimethyliminoacyl 
Table 2

Selected bond lengths $(\AA)$ and angles $\left({ }^{\circ}\right)$ for 10

\begin{tabular}{llll}
\hline $\mathrm{Mo}(1)-\mathrm{N}(1)$ & $1.706(8)$ & $\mathrm{Mo}(1)-\mathrm{C}(1)$ & $2.252(12)$ \\
$\mathrm{Mo}(1)-\mathrm{C}(2)$ & $2.256(13)$ & $\mathrm{Mo}(1)-\mathrm{Cl}(1)$ & $2.481(3)$ \\
$\mathrm{Mo}(1)-\mathrm{C}(11)$ & $2.46(1)$ & $\mathrm{Mo}(1)-\mathrm{C}(12)$ & $2.53(1)$ \\
$\mathrm{Mo}(1)-\mathrm{C}(13)$ & $2.40(1)$ & $\mathrm{Mo}(1)-\mathrm{C}(14)$ & $2.31(1)$ \\
$\mathrm{Mo}(1)-\mathrm{C}(15)$ & $2.34(1)$ & $\mathrm{N}(1)-\mathrm{C}(3)$ & $1.46(2)$ \\
$\mathrm{C}(3)-\mathrm{C}(5)$ & $1.27(3)$ & $\mathrm{C}(3)-\mathrm{C}(6)$ & $1.38(3)$ \\
$\mathrm{C}(3)-\mathrm{C}(1)$ & $1.50(3)$ & $\mathrm{C}(11)-\mathrm{C}(12)$ & $1.38(2)$ \\
$\mathrm{C}(11)-\mathrm{C}(15)$ & $1.47(2)$ & $\mathrm{C}(12)-\mathrm{C}(13)$ & $1.36(2)$ \\
$\mathrm{C}(13)-\mathrm{C}(14)$ & $1.40(2)$ & $\mathrm{C}(14)-\mathrm{C}(15)$ & $1.40(2)$ \\
$\mathrm{Mo}(1)-\mathrm{Cp}(1)$ & 2.096 & & $88.6(5)$ \\
$\mathrm{N}(1)-\mathrm{Mo}(1)-\mathrm{C}(1)$ & $88.4(5)$ & $\mathrm{N}(1)-\mathrm{Mo}(1)-\mathrm{C}(2)$ & $123.3(3)$ \\
$\mathrm{C}(1)-\mathrm{Mo}(1)-\mathrm{C}(2)$ & $137.1(5)$ & $\mathrm{N}(1)-\mathrm{Mo}(1)-\mathrm{Cl}(1)$ & $73.2(4)$ \\
$\mathrm{C}(1)-\mathrm{Mo}(1)-\mathrm{Cl}(1)$ & $73.1(4)$ & $\mathrm{C}(2)-\mathrm{Mo}(1)-\mathrm{Cl}(1)$ & 110.3 \\
$\mathrm{C}(3)-\mathrm{N}(1)-\mathrm{Mo}(1)$ & $175.1(9)$ & $\mathrm{Cp}(1)-\mathrm{Mo}(1)-\mathrm{Cl}(1)$ & 108.5 \\
$\mathrm{Cp}(1)-\mathrm{Mo}(1)-\mathrm{N}(1)$ & 126.3 & $\mathrm{Cp}(1)-\mathrm{Mo}(1)-\mathrm{C}(1)$ & 10 \\
$\mathrm{Cp}(1)-\mathrm{Mo}(1)-\mathrm{C}(2)$ & 107.5 & & \\
\hline
\end{tabular}

Cp $(1)$ is the centroid of the $C(11)$ to $C(15)$ ring.

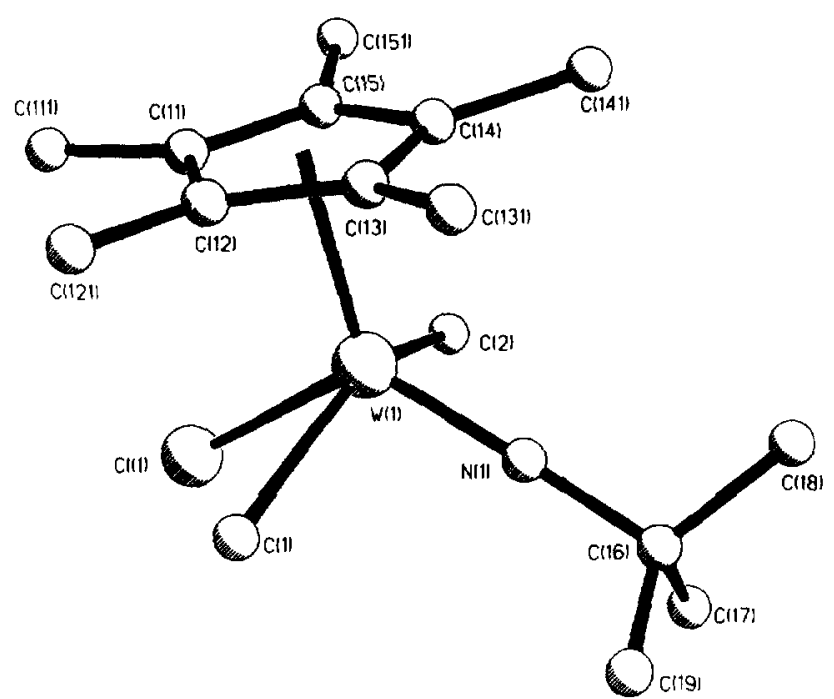

Fig. 3. Perspective view of the molecular structure of $\left[\mathrm{WCp}{ }^{*} \mathrm{Cl}\right.$ $\left.\mathrm{Me}_{2}\left(\mathrm{~N}^{\prime} \mathrm{Bu}\right)\right]$ (12) with the atom-numbering scheme. Hydrogen atoms are omitted for clarity.

complex $\left[\mathrm{WCp}^{*}\left\{\mathrm{C}(\mathrm{Me})=\mathrm{N}\left(2,6-\mathrm{Me}_{2} \mathrm{C}_{6} \mathrm{H}_{3}\right)\right\} \mathrm{Me}_{2}\left(\mathrm{~N}^{\prime} \mathrm{Bu}\right)\right]$ (16) as a red crystalline solid. Formulation of complex 16 containing the monohapto-coordinated iminoacyl ligand and two trans W-bonded methyl groups is consistent with its analytical composition and the observed ${ }^{1} \mathrm{H}$ and ${ }^{13} \mathrm{C}$ NMR spectra which show the low-field resonance of the migrated methyl group displaced to $\delta 2.39$, one singlet at $\delta 1.15$ for the other two equivalent metal-bonded methyl substituents and the low-field resonance due to the iminoacyl carbon atom at $\delta 230.0$. Complex 16 is a very air-sensitive compound soluble in all alkanes and aromatic solvents.

All the di- and tri-methyl tungsten complexes 11-12, 14 15 were characterized by their analytical composition and IR, ${ }^{1} \mathrm{H}$ and ${ }^{13} \mathrm{C}$ NMR spectroscopies, and the molecular structure of the dimethyl complex 12 was studied by $\mathrm{X}$-ray diffraction methods. The molecular structure is shown in Fig. 3 with the
Table 3

Selected bond lengths $(\AA)$ and angles $\left({ }^{\circ}\right)$ for 12

\begin{tabular}{lclc}
\hline $\mathrm{W}(1)-\mathrm{N}(1)$ & $1.739(6)$ & $\mathrm{W}(1)-\mathrm{C}(1)$ & $2.205(8)$ \\
$\mathrm{W}(1)-\mathrm{C}(2)$ & $2.221(8)$ & $\mathrm{W}(1)-\mathrm{Cl}(1)$ & $2.474(2)$ \\
$\mathrm{W}(1)-\mathrm{C}(11)$ & $2.539(7)$ & $\mathrm{N}(1)-\mathrm{C}(16)$ & $1.439(11)$ \\
$\mathrm{C}(11)-\mathrm{C}(12)$ & $1.412(11)$ & $\mathrm{C}(11)-\mathrm{C}(15)$ & $1.414(10)$ \\
$\mathrm{C}(12)-\mathrm{C}(13)$ & $1.424(11)$ & $\mathrm{C}(13)-\mathrm{C}(14)$ & $1.437(11)$ \\
$\mathrm{C}(14)-\mathrm{C}(15)$ & $1.410(11)$ & $\mathrm{C}(16)-\mathrm{C}(19)$ & $1.47(2)$ \\
$\mathrm{C}(16)-\mathrm{C}(18)$ & $1.53(2)$ & $\mathrm{C}(16)-\mathrm{C}(17)$ & $1.54(2)$ \\
$\mathrm{W}(1)-\mathrm{Cp}(1)$ & 2.097 & & \\
$\mathrm{~N}(1)-\mathrm{W}(1)-\mathrm{C}(1)$ & $88.2(3)$ & $\mathrm{N}(1)-\mathrm{W}(1)-\mathrm{C}(2)$ & $88.4(3)$ \\
$\mathrm{C}(1)-\mathrm{W}(1)-\mathrm{C}(2)$ & $140.0(4)$ & $\mathrm{N}(1)-\mathrm{W}(1)-\mathrm{Cl}(1)$ & $123.4(2)$ \\
$\mathrm{C}(1)-\mathrm{W}(1)-\mathrm{Cl}(1)$ & $73.9(3)$ & $\mathrm{C}(2)-\mathrm{W}(1)-\mathrm{Cl}(1)$ & $75.0(3)$ \\
$\mathrm{W}(1)-\mathrm{N}(1)-\mathrm{C}(16)$ & $177.2(6)$ & $\mathrm{Cp}(1)-\mathrm{W}(1)-\mathrm{Cl}(1)$ & 111.1 \\
$\mathrm{Cp}(1)-\mathrm{W}(1)-\mathrm{N}(1)$ & 125.5 & $\mathrm{Cp}(1)-\mathrm{W}(1)-\mathrm{C}(1)$ & 106.8 \\
$\mathrm{Cp}(1)-\mathrm{W}(1)-\mathrm{C}(2)$ & 107.5 & & \\
\hline
\end{tabular}

$\mathrm{Cp}(1)$ is the centroid of the $\mathrm{C}(11)$ to $\mathrm{C}(15)$ ring.

labelling scheme employed and selected bond distances and angles are presented in Table 3.

Complex 12 shows a pseudo-square pyramidal coordination analogous to that described for complex 10, with the chlorine atom trans to the imido $\mathrm{N}^{\prime} \mathrm{Bu}$ group with the $\mathrm{N}$ atom out of the plane defined by the other three ligands. The W I$\mathrm{N}]$ bond distance of $1.739(6) \AA$ is almost the same as that found for complex 9 and the W1-N1-Cl6 bond angle of $177.2(6)^{\circ}$ is slightly larger. The only remarkable difference is the $\mathrm{W}-\mathrm{Cl}$ bond distance which at $2.474(2) \AA$, is significantly larger than the distance observed in complex 9 (mean $2.404 \AA$ ) consistent with the shorter $\mathrm{Cp}^{*}$ (centroid)-W distance of $2.097 \AA$.

\section{Experimental}

All manipulations were carried out under a dry argon atmosphere either in a Vacuum Atmosphere Dri-lab or by standard Schlenk techniques. Solvents were dried and freshly distilled: hexane from sodium-potassium alloy, diethyl ether and THF from sodium-benzophenone, toluene from sodium and dichloromethane from calcium hydride. Reagent grade LiMe (1.6 $\mathrm{M}$ in $\mathrm{OEt}_{2}$, Aldrich), $\mathrm{MgClMe} \mathrm{(3.0} \mathrm{M} \mathrm{in} \mathrm{THF),}$ $\mathrm{PCl}_{5}$ (Aldrich), acetic acid (Panreac) and $\mathrm{N}^{\prime} \mathrm{BuH}_{2}$ (Aldrich) were purchased from commercial sources and were used without further purification. $\mathrm{NaCp}$ and the complexes $\mathrm{MoCp}^{*} \mathrm{Cl}_{2}\left(\mathrm{~N}^{\prime} \mathrm{Bu}\right)$ [7e], [ $\left.\mathrm{MoCp} * \mathrm{Cl}\left(\mathrm{N}^{t} \mathrm{Bu}\right)\right]_{2}$ [15], W(CO) $3^{-}$ $(\mathrm{NCMe})_{3}[12], \mathrm{WCpCl}_{2}(\mathrm{~N} \cdot \mathrm{Bu})$ [ 16], [MoCp*$\left.(\mathrm{CO})_{2}\right]_{2}$ and $\left[\mathrm{WCp}^{*}(\mathrm{CO})_{2}\right\rfloor_{2}[14 \mathrm{~b}]$ were prepared following modified reported methods. IR spectra were recorded on a PerkinElmer 583 spectrophotometer $\left(4000-200 \mathrm{~cm}^{-1}\right)$ as Nujol mulls between CsI or polyethylene pellets. ${ }^{1} \mathrm{H}$ and ${ }^{13} \mathrm{C}$ NMR spectra were recorded on Varian Unity VXR $300 \mathrm{MHz}$ and Varian Unity FT $500 \mathrm{MHz}$ instruments. Chemical shifts were measured relative to residual resonances in the deuterated solvents $\mathrm{C}_{6} \mathrm{D}_{6}(87.15), \mathrm{CDCl}_{3}(\delta 7.24)$ and $\mathrm{C}_{6} \mathrm{D}_{6}(\delta 128.0)$, $\mathrm{CDCl}_{3}(\delta 77.0)$, respectively. Mass spectra were recorded 
on an HP $5988 \mathrm{~A}$ instrument. $\mathrm{C}, \mathrm{H}$, and $\mathrm{N}$ analyses were carried out with a Perkin-Elmer $240 \mathrm{C}$ microanalyzer.

\subsection{Preparation of [WCp $\left.(\mathrm{CO})_{3} \mathrm{H}\right]$}

This compound was isolated by a method analogous to that reported by Fischer [13], using $\mathrm{W}(\mathrm{CO})_{3}(\mathrm{NCMe})_{3}$ instead of $\mathrm{W}(\mathrm{CO})_{6}$. To a suspension of $\mathrm{W}(\mathrm{CO})_{3}(\mathrm{NCMe})_{3}(6.00 \mathrm{~g}$, $15.3 \mathrm{mmol})$ in THF (200 $\mathrm{ml})$ was added freshly prepared $\mathrm{NaCp}(1.35 \mathrm{~g}, 15.3 \mathrm{mmol})$ and the mixture was stirred at $25^{\circ} \mathrm{C}$ for $2 \mathrm{~h}$. The mixture was then treated with acetic acid $(0.92 \mathrm{~g}, 0.88 \mathrm{ml}, 15.3 \mathrm{mmol})$ and vigorously stirred for 10 min. After elimination of volatiles under vacuum the solid residue was extracted into pentane $(2 \times 25 \mathrm{ml})$ to give a solution which by evaporation under vacuum afforded a yellow crystalline solid identified as $\mathrm{WCp}(\mathrm{CO}){ }_{3} \mathrm{H}$ by elemental analysis and comparison of its IR and NMR spectra with reported data [13]. Yield $4.86 \mathrm{~g}, 14.6 \mathrm{mmol}, 95 \%$.

\subsection{Preparation of $\left[\mathrm{MoCp}^{*} \mathrm{Cl} /(\mathrm{I})\right.$}

A solution of $\left[\mathrm{MoCp} *(\mathrm{CO})_{2}\right]_{2}(1.00 \mathrm{~g}, 1.72 \mathrm{mmol})$ in toluene $(40 \mathrm{ml})$ was slowly added to a solution of $\mathrm{PCl}_{5}$ $(1.50 \mathrm{~g}, 7.2 \mathrm{mmol})$ in toluene $(50 \mathrm{ml})$ and the mixture was stirred at $25^{\circ} \mathrm{C}$ for $2 \mathrm{~h}$ and then at $75^{\circ} \mathrm{C}$ for 1 day to give a purple solid which was filtered, washed with dichloromethane $(2 \times 10 \mathrm{ml})$ and dried under vacuum to be characterized as the title compound. Yield $1.20 \mathrm{~g}, 1.61 \mathrm{mmol}, 93 \%$. Anal. Calc. for $\mathrm{C}_{10} \mathrm{H}_{15} \mathrm{Cl}_{4} \mathrm{Mo}$ : C, 32.19; H, 4.02. Found: C, $31.74 ;$ H. $4.00 \%$.

\subsection{Preparation of $\left[\mathrm{WCpCl}_{4}\right](2)$}

This compound was prepared following a method similar to that described by Green et al. [11] but using $\mathrm{WCp}(\mathrm{CO}){ }_{3} \mathrm{H}$ instead of $\mathrm{WCp}(\mathrm{CO})_{3} \mathrm{Me}$. A solution of $\mathrm{WCp}(\mathrm{CO})_{3} \mathrm{H}$ $(4.00 \mathrm{~g}, 12.0 \mathrm{mmol})$ in dichloromethane $(100 \mathrm{ml})$ was added dropwise to a stirring solution of phosphorus pentachloride $(7.48 \mathrm{~g}, 36.0 \mathrm{mmol})$ in the minimum amount of dichloromethane at $25^{\circ} \mathrm{C}$ with evolution of a colourless gas. The mixture was stirred for $20 \mathrm{~h}$. Then the solvent was removed by filtration leaving a red-brown solid which was washed with dichloromethane $(3 \times 20 \mathrm{ml})$ dried in vacuo and identified as complex 2 by elemental analysis and comparison of its IR spectrum with reported data [11]. Yield $4.59 \mathrm{~g}$, $11.5 \mathrm{mmol}, 98 \%$

\subsection{Preparation of $\left[\mathrm{WCP}^{*} \mathrm{Cl}_{4}\right](3)$}

A solution of $\left[\mathrm{WCp}^{*}(\mathrm{CO})_{2}\right]_{2}(2.00 \mathrm{~g}, 2.66 \mathrm{mmol})$ in toluene $(40 \mathrm{ml})$ was slowly added to a solution of $\mathrm{PCl}_{5}$ $(2.35 \mathrm{~g}, 11.3 \mathrm{mmol})$ in toluene $(50 \mathrm{ml})$ and the mixture was stirred at $25^{\circ} \mathrm{C}$ for $2 \mathrm{~h}$ and then at $75^{\circ} \mathrm{C}$ for 2 days to give a yellow-orange solid which was filtered, washed with dichloromehane $(2 \times 10 \mathrm{ml})$ and dried under vacuum to be characterized as the title compound. Yield $2.25 \mathrm{~g} .2 .44 \mathrm{mmol}$,
92\%. Anal. Calc. for $\mathrm{C}_{10} \mathrm{H}_{15} \mathrm{Cl}_{4} \mathrm{~W}: \mathrm{C}, 26.05 ; \mathrm{H}, 3.25$. Found: $\mathrm{C}, 26.03 ; \mathrm{H}, 3.61 \%$.

\subsection{Preparation of $\left[\mathrm{MoCp} p^{*} \mathrm{Cl},\left[N^{t} \mathrm{Bu}\right)\right](7)$}

A $\mathrm{CH}_{2} \mathrm{Cl}_{2}(50 \mathrm{ml})$ solution of complex $4(0.59 \mathrm{~g}$, $1.58 \mathrm{mmol}$ ) was prepared and the stoichiometric amount of $\mathrm{PCl}_{5}(0.17 \mathrm{~g}, 0.81 \mathrm{mmol})$ was added. The solution colour changed quickly from the initial brown to orange-sed. The solution was stirred for $2 \mathrm{~h}$ and then filtered. After removal of the solvent, an orange-red solid was obtained. The residue was washed whith $\sim 15 \mathrm{ml}$ of pentane and extracted with toluene $(2 \times 30 \mathrm{ml})$. The solution was concentrated to give a microcrystalline orange solid identified as 7 . Yield $0.56 \mathrm{~g}$, $1.37 \mathrm{mmol}, 87 \%$. The same procedure can also be used starting from the imidomolybdenum(IV) complex [ MoCp* . $\left.\mathrm{Cl}\left(\mathrm{N}^{\prime} \mathrm{Bu}\right)\right]_{2}[15]$. IR (Nujol mull, $\left.\nu\left(\mathrm{cm}^{-1}\right)\right): 1212(\mathrm{sh})$, 1201 (vs), $1031(\mathrm{~m}), 793(\mathrm{~m}), 369(\mathrm{w}), 349$ (s), 324 (vs), $297(\mathrm{w})$. 'H NMR ( $\delta \mathrm{ppm}$, in $\left.\mathrm{C}_{6} \mathrm{D}_{6}\right): 1.79\left(\mathrm{~s}, 15 \mathrm{H}, \mathrm{C}_{5} M e_{5}\right)$, $1.23\left(\mathrm{~s}, 9 \mathrm{H}, \mathrm{NCMe}_{3}\right)$. Anal. Calc. for $\mathrm{C}_{14} \mathrm{H}_{24} \mathrm{NCl}_{3} \mathrm{Mo}$ : C, $41.13 ; \mathrm{H}, 5.87 ; \mathrm{N}, 3.43$. Found: C, 41.33; H, 5.93; N, 3.29\%.

\subsection{Preparation of $/ \mathrm{WCpCl}_{3}\left(N^{\prime} B u\right) /(8)$}

Following the method reported by Green et al. [16], $\mathrm{WCpCl}_{2}\left(\mathrm{~N}^{\mathrm{t}} \mathrm{Bu}\right)$ was prepared by addition of $\mathrm{NH}_{2}^{\mathrm{t}} \mathrm{Bu}(2.52 \mathrm{~g}$, $3.6 \mathrm{ml}, 34.5 \mathrm{mmol})$ to a toluene $(150 \mathrm{ml})$ solution of $\mathrm{WCpCl}_{4}(4.5 \mathrm{~g}, 11.5 \mathrm{mmol})$ and used in situ by adding $\mathrm{PCl}_{5}$ $(1.20 \mathrm{~g}, 5.8 \mathrm{mmol})$. After stirring for $20 \mathrm{~h}$ at $25^{\circ} \mathrm{C}$ the insoluble residue was removed by filtration and the toluene solution together with that obtained after washing the solid with dichloromethane $(2 \times 50 \mathrm{ml})$ was evaporated to dryness to afford a solid, which after being washed with pentane was identified as complex $8(4.17 \mathrm{~g}, 9.8 \mathrm{mmol}, 81 \%$ yield $)$. ${ }^{\prime} \mathrm{H}$ NMR $\left(\delta \mathrm{ppm}\right.$, in $\left.\mathrm{CDCl}_{3}\right): 6.69\left(\mathrm{~s}, 5 \mathrm{H}, \mathrm{C}_{5} H_{5}\right), 1.51(\mathrm{~s}, 9 \mathrm{H}$, $\left.\mathrm{NCMe}_{3}\right) .{ }^{13} \mathrm{C}\left\{{ }^{1} \mathrm{H}\right\}$ NMR $\left(\delta \mathrm{ppm}\right.$, in $\left.\mathrm{CDCl}_{3}\right): 115.2(\mathrm{~s}$, $\left.\mathrm{C}_{5} \mathrm{H}_{5}\right), 77.5$ ( $\left.\mathrm{s}, \mathrm{CMe}_{3}\right), 28.4$ (s, $\left.\mathrm{CMe}_{3}\right)$. Anal. Calc. for $\mathrm{C}_{9} \mathrm{H}_{14} \mathrm{Cl}_{3} \mathrm{NW}$ : C, 25.41; H, 3.32; N, 3.31. Found: C, 26.06; $\mathrm{H}, 3.75 ; \mathrm{N}, 3.50 \%$.

\subsection{Preparation of $\left[W C p^{*} C l_{3}\left(N^{\prime} B u\right) /(9)\right.$}

A solution of $\mathrm{WCp}^{*} \mathrm{Cl}_{2}\left(\mathrm{~N}^{\prime} \mathrm{Bu}\right)$ prepared by reacting $\mathrm{WCp}^{*} \mathrm{Cl}_{4}(1.00 \mathrm{~g}, 2.2 \mathrm{mmol})$ with $\mathrm{NH}_{2}{ }^{\prime} \mathrm{Bu}(0.69 \mathrm{ml}$, $6.6 \mathrm{mmol})$ in toluene $(50 \mathrm{ml})$ was treated with $\mathrm{PCl}_{5}(0.23 \mathrm{~g}$, $1.08 \mathrm{mmol}$ ). The colour of the solution changed from green to yellow and after stirring for $4 \mathrm{~h}$ at $25^{\circ} \mathrm{C}$ the insoluble solid was removed by filtration. The toluene solution was cooled to $-35^{\circ} \mathrm{C}$ to give orange crystals of complex $9(1.0 \mathrm{~g}$, $2.0 \mathrm{mmol}, 92 \%)$. ' $\mathrm{H} \mathrm{NMR}\left(\delta \mathrm{ppm}\right.$, in $\left.\mathrm{CDCl}_{3}\right): 1.96(\mathrm{~s}, 15 \mathrm{H}$, $\left.\mathrm{C}_{5} \mathrm{Me}_{5}\right), 1.22\left(\mathrm{~s}, 9 \mathrm{H}, \mathrm{NCMe}_{3}\right) .{ }^{13} \mathrm{C}\left({ }^{1} \mathrm{H}\right\} \mathrm{NMR}(\delta \mathrm{ppm}$, in $\left.\mathrm{CDCl}_{3}\right): 125.4\left(\mathrm{~s}, \mathrm{C}_{5} \mathrm{Me}_{5}\right), 76.0\left(\mathrm{~s}, \mathrm{CMe}_{3}\right), 28.9\left(\mathrm{~s}, \mathrm{CMe}_{3}\right)$, $12.7\left(\mathrm{~s}, \mathrm{C}_{5} \mathrm{Me}_{5}\right.$ ). Anal. Calc. for $\mathrm{C}_{14} \mathrm{H}_{40} \mathrm{Cl}_{3} \mathrm{NW}: \mathrm{C}, 33.87 ; \mathrm{H}$, 4.83; N, 2.82. Found: C, 34.16; H, 4.82; N, $2.97 \%$. 


\subsection{Preparation of $\left(\mathrm{MoCp}^{*} \mathrm{Cl} \mathrm{Me}_{2}\left(N^{\prime} \mathrm{B} u\right) /(10)\right.$}

A suspension of $7(0.40 \mathrm{~g}, 0.98 \mathrm{mmol})$ in $\mathrm{Et}_{2} \mathrm{O}(60 \mathrm{ml})$ was cooled to approximately $-65^{\circ} \mathrm{C}$, then 2 equiv. $(1.22 \mathrm{ml})$ of a $\mathrm{LiMe}\left(1.6 \mathrm{M}\right.$ in $\mathrm{Et}_{2} \mathrm{O}$ ) solution were added. The mixture was stirred at room temperature for $3 \mathrm{~h}$. After filtration the solution was concentrated to $\sim 10 \mathrm{ml}$ giving an orange crystalline compound identified as complex $10(0.31 \mathrm{~g} .80 \%$ yield). 'H NMR ( $\delta \mathrm{ppm}$, in $\left.\mathrm{C}_{t} \mathrm{D}_{(}\right): 1.55$ ( $\left.\mathrm{s} .15 \mathrm{H} . \mathrm{C}_{\mathrm{s}} \mathrm{Me}_{\mathrm{s}}\right)$. 1.99 (s. $9 \mathrm{H}, \mathrm{NCMe}$ ) 1.53 (s. 6H. Mo-Mc $\mathrm{c}_{2}$. Ancil. Calc. for $\mathrm{C}_{10} \mathrm{H}_{30} \mathrm{NClMo}$ : C, $52.25: \mathrm{H}, 8.16: \mathrm{N}, 3.81$. Found: $\mathrm{C}$. $52.41: \mathrm{H}, 8.11 ; \mathrm{N}, 3.89 \%$.

\subsection{Preparation of $\left[W C p C l M e_{2}^{2}\left(N^{\prime} B u\right)\right\}(I I)$}

To a suspension of $\mathrm{WCpCl}_{3}\left(\mathrm{~N}^{\prime} \mathrm{Bu}\right)$ ( $\left.1.00 \mathrm{~g}, 2.34 \mathrm{mmol}\right)$ in toluene $(50 \mathrm{ml})$ was added a $3.0 \mathrm{M}$ solution of $\mathrm{MgClMe}$ in THF ( $1.56 \mathrm{ml}, 0.35 \mathrm{~g}, 4.68 \mathrm{mmol})$ at $-78^{\circ} \mathrm{C}$ and the mixture was warmed to $25^{\circ} \mathrm{C}$ and stirred for $4 \mathrm{~h}$. The solution was filtered and the solvent removed under vacuum to give a solid, which after being washed with pentine $(2 \times 20 \mathrm{ml})$ wals dissolved in toluene and purified by chromatography (Shefadex) using toluene as eluent. The resulting green solution was concentrated and cooled to $-35^{\circ} \mathrm{C} 10$ atford complex 11 as a crystalline green solid (0.36 g. 0.94 mmol. 40\% yield). ' $\mathrm{H} \mathrm{NMR}\left(\delta \mathrm{ppm}\right.$, in $\left.\mathrm{CDCl}_{3}\right): 5.92\left(\mathrm{~s}, 5 \mathrm{H}, \mathrm{C}_{5} \mathrm{H}_{5}\right)$. $\left.1.28\left(\mathrm{~s} .9 \mathrm{H}, \mathrm{NCM} e_{3}\right), 1.23\left(\mathrm{~s} .6 \mathrm{H}, \mathrm{W}-M_{c_{2}}\right),{ }^{1 .} \mathrm{C}^{1}{ }^{1} \mathrm{H}\right\} \mathrm{NMR}$ $\left(\delta \mathrm{ppm}\right.$, in $\left.\mathrm{CDCl}_{3}\right): 104.9\left(\mathrm{~s}, \mathrm{C}_{5} \mathrm{H}_{5}\right), 70.6$ (s, $\left(\mathrm{Me}_{3}\right), 28.4$

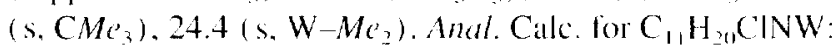
C. 34.26: H. 5.23: N. 3.63. Found: C. 32.72: H. 5.00: N, $3.28 \%$.

\section{10. Preparation of $/ W C p^{*} \mathrm{ClMe}_{2}\left(\mathrm{~N}^{\prime} \mathrm{BH}\right) /(12)$}

To a solution of $\mathrm{WCp}^{*} \mathrm{Cl}_{3}\left(\mathrm{~N}^{\prime} \mathrm{Bu}\right)$ (9) (1.11g. $2.22 \mathrm{mmol})$ in THF $(50 \mathrm{ml})$ cooled $10-78^{\circ} \mathrm{C}$ a $3.0 \mathrm{M}$ solution of $\mathrm{MgClMe}$ in THF $(1.50 \mathrm{ml}, 4.47 \mathrm{mmol})$ was added. then warmed to $25^{\circ} \mathrm{C}$ and stirred for $4 \mathrm{~h}$. The solvent was removed under vacuum and the resulting solid was extracted with pentane to give al red solution. The solution was concentrated under vacuum to give a crystalline yellow solid identified as complex $12(0.45 \mathrm{~g}, 0.99 \mathrm{mmol}, 4+6 \%$ yield $)$. 'H NMR ( $\delta$ ppm. in $\left.\mathrm{CDCl}_{3}\right): 1.63\left(\mathrm{~s} .15 \mathrm{H}, \mathrm{C}_{5} M e_{s}\right), 1.30$ (s. $\left.6 \mathrm{H}, \mathrm{W}-\mathrm{Me}_{2}\right), 1.03\left(\mathrm{~s}, 9 \mathrm{H}, \mathrm{NCM} e_{3}\right) .{ }^{13} \mathrm{C}\left\{{ }^{1} \mathrm{H}\right\} \mathrm{NMR}(\delta \mathrm{ppm}$. in $\left.\mathrm{CDCl}_{3}\right): 113.2\left(\mathrm{~s}, \mathrm{C}_{5} \mathrm{Me}_{5}\right), 70.5\left(\mathrm{~s}, \mathrm{CMe}_{3}\right), 32.2 \mathrm{~s}, \mathrm{~W}-$ $M e_{2}$ ). 28.7 (s. $\left.\mathrm{CMe}_{3}\right), 11.3$ (s, $\mathrm{C}_{5} M \mathrm{e}_{5}$ ). Anal. Calc. for $\mathrm{C}_{16}, \mathrm{H}_{30} \mathrm{ClNW}: \mathrm{C}, 42.19: \mathrm{H}, 6.59: \mathrm{N}, 3.07$. Found: C. 41.40 : H. 6.80: N. $2.87 \%$.

\subsection{Preparation of $[\mathrm{MoCp})^{*} \mathrm{Me}_{3}\left(\mathrm{~N}^{\prime} \mathrm{Bu}\right) /(13)$}

A suspension of complex $7(0.44 \mathrm{~g} .1 .077 \mathrm{mmol})$ in $\mathrm{n}$ hexane $(50 \mathrm{ml})$ was prepared and a $1.6 \mathrm{M}$ solution of lime in $\mathrm{OEL}_{2}(2.22 \mathrm{ml}, 3.55 \mathrm{mmol})$ was added at $-6.5^{\circ} \mathrm{C}$. The reaction mixture was warmed to $25^{\circ} \mathrm{C}$ and stirred for $2 \mathrm{~h}$. The red solution was filtered and evaporated 10 dryness and the orange oil residue was partially crystallized in the minimum amount of $\mathrm{Et}_{-} \mathrm{O}$ by cooling at $-78^{\circ} \mathrm{C}$. 'H NMR $(\delta \mathrm{ppm}$, in $\left.\mathrm{C}_{6} \mathrm{D}_{6}\right): 1.55$ (s. $\left.15 \mathrm{H}, \mathrm{C}_{5} \mathrm{Me}_{5}\right), 1.05\left(\mathrm{~s}, 9 \mathrm{H}, \mathrm{NCMe}_{3}\right), 0.96$ (s, 6H, Mo-Me $), 0.29$ (s. $3 \mathrm{H}$, trans Mo-Me). Anal. Calc for $\mathrm{C}_{17} \mathrm{H}_{33} \mathrm{NMO}: \mathrm{C} .58 .79: \mathrm{H}$. 9.51: N. 4.03. Found: C. 58.99: H. 9.37: N. $3.99 \%$.

\subsection{Preparaion of /WCpMe $\left(N^{\prime} B u\right) /(14)$}

To a solution of $\mathrm{WCpClMe}_{2}\left(\mathrm{~N}^{\prime} \mathrm{Bu}\right)$ (12) (1.5 g. $3.9 \mathrm{mmol}$ ) in toluene $(50 \mathrm{ml})$ a $3.0 \mathrm{M}$ solution of $\mathrm{MgClMe}$ in THF (0.30 g. $1.3 \mathrm{ml} .3 .9 \mathrm{mmol})$ was added at $-78^{\circ} \mathrm{C}$ and then warmed to $25^{\circ} \mathrm{C}$ and stirred for $4 \mathrm{~h}$. After filtration the solvent was removed under vacuum and the resulting brown solid was extracted into pentane. Evaporation of the solvent afforded a brown solid identificd as complex $14(0.72 \mathrm{~g}$. $1.95 \mathrm{mmol} .50 \%$ yield ). 'H NMR ( $\delta \mathrm{ppm}$, in $\left.\mathrm{CDCl}_{3}\right): 5.12$ (s. $\left.5 \mathrm{H}, \mathrm{C}_{5} H_{5}\right), 1.08\left(\mathrm{~s}, 6 \mathrm{H}\right.$, ais $\left.\mathrm{W}-\mathrm{Me}_{2}\right) .1 .02(\mathrm{~s}, 9 \mathrm{H}$, $\left.\mathrm{NCMe}_{3}\right), 0.79$ (s. 3H. trans $\left.\mathrm{W}-\mathrm{Me}\right){ }^{13} \mathrm{C}\left\{{ }^{\prime} \mathrm{H}\right\} \mathrm{NMR}(\delta \mathrm{ppm}$. in $\mathrm{CDCl}_{3}$ ): 103.4 (s. $\left.\mathrm{C}_{5} \mathrm{H}_{5}\right) .69 .1$ (s. $\left.\mathrm{CMe}_{3}\right) .28 .8$ (s. CMe $\mathrm{CM}_{3}$ ). 21.1 (s, trans $\mathrm{W}-\mathrm{Me}), 14.3$ (s, is $\mathrm{W}-\mathrm{Me}_{2}$ ). Anal. Calc for $\mathrm{C}_{12} \mathrm{H}_{23} \mathrm{NW}: \mathrm{C} .39 .44: \mathrm{H} .6 .35 ; \mathrm{N}, 3.84$. Found: $\mathrm{C}, 39.16 ; \mathrm{H}$. 6.59: N. $3.73 \%$

\section{1.. Preparation of / $W C)^{*} M e^{\prime},\left(N^{\prime} B u\right) /(15)$}

To a solution of $\mathrm{WCp}^{*} \mathrm{Cl}_{3}\left(\mathrm{~N}^{\prime} \mathrm{Bu}\right)$ (9) (1.33 g. $2.68 \mathrm{mmol}$ ) in THF $(50 \mathrm{ml}$, wals added a $3.0 \mathrm{M}$ solution of $\mathrm{MgClMe}$ in THF ( $2.68 \mathrm{ml} .8 .04 \mathrm{mmol})$ at $-78^{\circ} \mathrm{C}$. The mixture was warmed to $25^{\circ} \mathrm{C}$ and stirred for $4 \mathrm{~h}$. After removing the solvent under vacuum the resulting solid residue was extracted into pentane to give a red solution which was evaporated to dryness. The solid was purilied by chromatography (florisil) using hexance as eluent to afford after evaporation and cooling a red crystalline solid identified as complex $\mathbf{1 5}$ (0.40) $\mathrm{g}, 0.92 \mathrm{mmol} .35 \%$ yield). 'H NMR ( $\delta \mathrm{ppm}$, in $\left.\left.\mathrm{CDCl}_{3}\right): 1.60\right)\left(\mathrm{s} .15 \mathrm{H}, \mathrm{C}_{5} \mathrm{Me}_{5}\right) .1 .09\left(\mathrm{~s}, 9 \mathrm{H} . \mathrm{NCMe}_{3}\right), 0.89$ (s, 6H, cis W-Me $), 0.34$ (s. 3H. trans W-Me). ${ }^{13} \mathrm{C}\left\{{ }^{1} \mathrm{H}\right\}$ NMR ( $\delta \mathrm{ppm}$, in $\mathrm{CDCl}_{3}$ ): $1\left(19.6\right.$ ( s. $\left.\mathrm{C}_{5} \mathrm{Me}_{5}\right) .69 .8$ (s. $\mathrm{CMe}_{3}$ ),

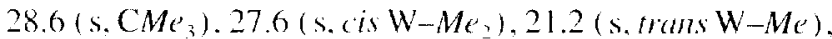
10.7 (s, $\mathrm{C}_{5} M \mathrm{e}_{5}$ ). Anal. Calc. for $\mathrm{C}_{17} \mathrm{H}_{33} \mathrm{NW}$ : C, 46.93: $\mathrm{H}$. 7.58: N. 3.22. Found: C. 46.39; H. 7.63: N, $2.90 \%$

\subsection{Preparation of $/ W C P^{*} M e / \eta-C(M e)=N(2,6$ $\left.M e_{2} C_{1} H_{j}\right) /\left(N^{\prime} B u\right) /(\mathrm{IO})$}

An ampoule containing a solution of $\mathrm{WCp}^{*} \mathrm{Me}_{3}\left(\mathrm{~N}^{\prime} \mathrm{Bu}\right)$ (15) (0.92g. $2.12 \mathrm{mmol})$ and an excess of $\mathrm{CN}(2.6-$ $\left.\mathrm{Me}_{2} \mathrm{C}_{6} \mathrm{H}_{3}\right)(1.40 \mathrm{~g}, 10.56 \mathrm{mmol})$ in toluene $(50 \mathrm{ml})$ was sealed under vacuum. By heating $1065^{\circ} \mathrm{C}$ a very slow reaction was observed, that required 15 days to be complete, the colour of the solution changing from an orange to a deep red colour. After filtering the solvent $w$ as removed under vacuum and the resulting solid residue was recrystallized from hexane to give a red solid identified as complex 16 in $60 \%$ / yield. ' $\mathrm{H}$ NMR ( $8 \mathrm{ppm}$, in $\left.\mathrm{C}_{6} \mathrm{D}_{6}\right): 7.10(\mathrm{~d}, 2 \mathrm{H}, \mathrm{m}-\mathrm{Ph}), 6.91(1,1 \mathrm{H} . p-$ 


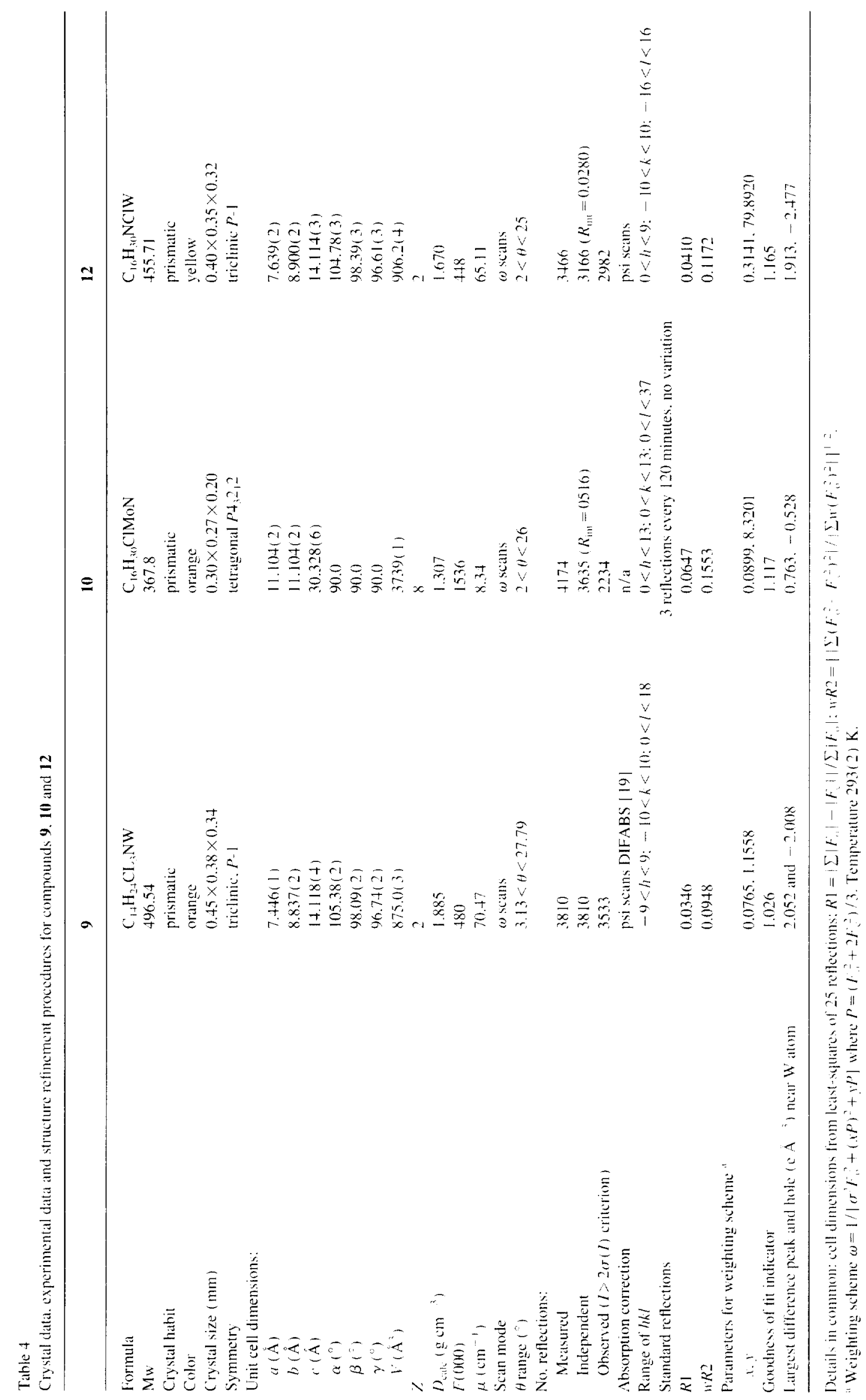


$\mathrm{Ph}), 2.39(\mathrm{~s}, 3 \mathrm{H}, \mathrm{C}-M e), 2.33\left(\mathrm{~s}, 6 \mathrm{H}, M e_{2} \mathrm{C}_{6} \mathrm{H}_{3}\right), 1.71(\mathrm{~s}$, $\left.15 \mathrm{H}, \mathrm{C}_{5} M e_{5}\right), 1.15$ (s, 6H, WMe $\left.e_{2}\right), 0.95$ (s, 9H, NCMe $e_{3}$ ). ${ }^{13} \mathrm{C}\left({ }^{1} \mathrm{H}\right\}$ NMR $\left(\delta \mathrm{ppm}\right.$, in $\left.\mathrm{C}_{6} \mathrm{D}_{6}\right): 230.0(\mathrm{~s}, \mathrm{~N}=C \mathrm{Me}), 154.0$ ( s, N-Ph-ipso), $128.0(\mathrm{~s}, o-\mathrm{Ph}), 126.7(\mathrm{~s}, \mathrm{~m}$-Ph), $120.8(\mathrm{~s}$, $p-\mathrm{Ph}), 112.1\left(\mathrm{~s}, \mathrm{C}_{5} \mathrm{Me}_{5}\right), 69.5\left(\mathrm{~s}, \mathrm{CMe}_{3}\right), 33.0\left(\mathrm{~s}, \mathrm{~W}-\mathrm{Me}_{2}\right)$, $28.9\left(\mathrm{~s}, \mathrm{CMe} e_{3}\right), 19.8\left(\mathrm{~s}, \mathrm{Me}_{2} \mathrm{C}_{6} \mathrm{H}_{3}\right), 17.0(\mathrm{~s}, \mathrm{~N}=\mathrm{CMe}), 10.9$ (s, $\mathrm{C}_{5} M e_{5}$ ).

\subsection{Crystal structure determinations}

Suitably sized orange crystals of 9 were obtained by crystallization from toluene; crystals of 10 were obtained by cooling a diethyl ether solution to $-40^{\circ} \mathrm{C}$ and crystals of 12 were obtained by cooling its hexane solution. The crystals were mounted in sealed tubes under Argon in an Enraf-Nonius CAD-4 automatic four-circle diffractometer with bisecting geometry, using graphite-oriented monochromator and Mo $K \alpha(\lambda=0.71073 \AA)$ radiation. Crystallographic and experimental details are summarized in Table 4. Data were collected at room temperature. Intensities were corrected for Lorentz and polarization effects in the usual manner. Absortion was corrected by Psi scans in 9 and 12. Extinction correction was made in $\mathbf{1 2}$ with extinction coefficient of $0.036(3)$ where $\left.F_{c}^{*}=k F_{\mathrm{c}} \mid 1+0.001 F_{c}^{2} \lambda^{3} / \sin (2 \theta)\right]^{-1 / 4}$. The structures were solved by a combination of heavy atoms, direct methods, and Fourier synthesis by SHELX90 [20] program and refined on $F^{2}$ by full-matrix least-squares calculations (SHELX93) 1211. All non-hydrogen atoms were refined anisotropically. In the last cycle of refinement hydrogen atoms were introduced from geometric calculations and with fixed thermal parameters.

All calculations were performed on an Alpha AXP Digital Workstation.

\section{Supplementary material}

Tables of atomic coordinates, complete lists of bond distances and angles, anisotropic displacement parameters, hydrogen coordinates and isotropic displacement parameters and structure factors for $\mathbf{9 , 1 0}$ and 12 are available from the authors on request.

\section{Acknowledgements}

The authors acknowledge DGICYT (Project PB92-0178C) and CAM (I+D 0033/94) for financial support.

\section{References}

(1) (a) R.R. Schrock, S. Luo, N.C. Zanetti and H.H. Fox, Organometallics, 1.3 (1994) 3396; (b) W.J. Feast, V.C. Gibson, K.J. Ivin, A.M. Kenwright and E. Khosravi, J. Chem. Soc., Chem. Commun., (1994) 1399; (c) H.H. Fox, R.R. Schrock and R. O'Dell, Organometallics, 13 ( 1994 ) 6.35: (d) W.M. Vaughan, K.A. Abhoud and J.M. Boncella, J. Organomet. Chem.. 485 (1995) 37; (e) F.J. Schaltermann, R.R. Schrock and W.M. Davis, J. Am. Chem. Soc., 118 (1996) 3295; (f) A. Bell, US Patent 5194534 (1993).
[2] H.H. Fox, M.O. Wolf, R. O'Dell, B.L. Lin, R.R. Schrock and M.S Wrighton, J. Am. Chem. Soc.. 116 (1994) 2827.

[3] (a) D.M.-T. Chang, W.C. Fultz, W.A. Nugent, D.C. Roe and T.H. Tulip, J. Am. Chem. Soc., 107 (1985) 251; (b) J.D. Burrington, C.T. Kartisek and R.K. Grasselli, J. Catal., 87 (1984) 363.

$14 \mid$ (a) D.L. Morrison and D.E. Wigley, Inorg. Chem., 34 (1995) 2610; (b) P.W. Dyer, V.C. Gibson, J.A.K. Howard, B. Whittle and C. Wilson, Polyhedron, 14 (1995) 103; (c) P.W. Dyer. V.C. Gibson and W. Clegg, J. Chem. Soc., Dalton Trans., (1995) 3313; (d) T.A. Coffey and G. Hogarth, Polyhedron. 16 (1996) 165; (e) V.C. Gibson, C. Redshaw, W. Clegg, M.R.J. Elsegood, U. Siemeling and T. Türk, J. Chem. Soc., Dalton Trans., (1996) 4513; (f) V.C. Gibson. E.L. Marshall, C. Redshaw, W. Clegg and M.R.J. Elsegood, J. Chem. Soc.. Dalton Trans., (1996) 4197.

15| (a) D.D. van der Leude, K.A. Abboud and J.M. Boncella, Organometallics, 13 (1994) 3378; (b) K.R. Powell. P.J. Pérez, L. Luden, S.G. Feng, P.S. White, M. Brookhardt and J.L. Templeton, Organometallics, 13 (1994) 1851; (c) P.C. McGowan, S.T. Massey, K.A. Abboud and L. McElwee-White, J. Am. Chem. Soc., 116 (1994) 7419; (d) G.D. Forster and G. Hogarth, J. Organomet. Chem., 471 (1994) 161; (e) W.M. Vaughan. K.A. Abboud and J.M. Boncella, J. Am. Chem. Soc., 117 (1995) 11015; (f) D.L. Morrison, P.M. Rodgers, Y.W. Chao, M.A. Bruck. C. Grittini, T.L. Tajima, S.J. Alexander, A.L. Rheingold and D.E. Wigley, Organometallics, 14 (1995) 2435: (g) G.R. Clark, A.J. Nielson and C.E.F. Rickard, J. Chem. Soc., Dalton Trans., (1995) 1907.

[6] D.E. Wigley, Prog. Inorg. Chem., 42 (1994) 239.

[7] (a) J. Sundermeyer, U. Radius and C. Burschka, Chem. Ber., 125 ( 1992) 2379; (b) W.A. Herrmann, G. Weichselbaumer, R.A. Paciello, R.A. Fischer. E. Herdtweck, J. Okuda and D.W. Marz, Organometallics, 9 (1990) 489; (c) M.S. Rau, C.M. Kretz, G.L. Geoffrey, A.L. Rheingold and B.S. Haggerty, Organometallics, 13 ( 1994) 1624; (d) M.L.H. Green. P.C. Konidaris and P. Mountford, J. Chem. Soc., Dalton Trans., (1994) 2975; (e) K. Köhler, H.W. Roesky, A. Herzog. H. Gornitzka, A. Steinet and l. Usón, Inorg. Chem., 35 (1996) 1773; (f) P. Bhallacharyya, J. Fawcet, J.H. Holloway, E.G. Hope and G.C. Saunders, J. Chem. Soc., Dalton Trans., (1997) 199.

[8] (a) M. Gómez and P. Royo, Bull. Pol. Acad. Sci. Chem., 42 (1995) 422; (b) M.V. Galakhov, M. Gómez, G. Jiménez and P. Royo, Organometallics, 14 ( 1995 ) 2843; (c) M. Gómez, P. Gómez-Sal, G. Jiménez. A. Martín, P. Royo and J. Sánchez-Nieves, Organometallics, 15 (1996) 3579 .

19| F. Amor, P. Gómez-Sal, E. de Jesús, A. Martín, A.l. Pérez, P. Royo and A. Vázquez de Miguel, Organometallics, 15 (1996) 2103.

1101 (a) R.C. Murray, L. Blum, A.H. Liu and R.R. Schrock. Organometallics, 4 ( 1985 ) 953; (b) A.H. Liu, R.C. Murray, J.C. Dewan, B.D. Santarsiero and R.R. Schrock. J. Am. Chem. Soc., 109 (1987) 4282.

1111 M.L.H. Green, J.D. Hubert and P.J. Mountford, Chem. Soc., Dalton Trans., (1990) 3793.

| 12| U. Behrens, J. Organomet. Chem., 310 (1986) 335.

|13] E.O. Fischer, Inorg. Synth., 7 (1978) 136.

|14| (a) M.D. Curtis and R.J. Klingler, J. Organomet. Chem., 161 (1978) 23: (b) R.B. King, M.Z. Jqbal and A.D. King, J. Organomet. Chem., 171 ( 1979$) 53$.

|15| T. Pedraz, M.A. Pellinghelli, P. Royo, A. Tiripicchio and A. Vázquez de Miguel, J. Organomet. Chem., 534 ( 1997) 27.

$116 \mid$ M.L.H. Green, P.C. Konidaris. P. Mountlord and S.J. Simpson. J. Chem. Soc., Chem. Commun., (1992) 256.

[17] S.H. Hober, T.C. Baldwin and D.E. Wigley, Organometallics, 12 (1993) 91.

[18] T.E. Glassman. M.G. Vale and R.R. Schrock, Organometallics, 10 (1991) 4046.

( $19 \mid$ N. Walker and D. Stewart. DIFABS, Acta Crystallogr., Sect. A, 39 (1983) 158.

120| G.M. Sheldrick, Acta Crystallogr., Sect. A. 46 (1990) 467.

121| G.M. Sheldrick, SHELXL93, University of Göttingen. Germany, 1993. 